\title{
Geasters in the Western Ghats and west coast of India
}

\author{
Namera C. Karun, Kandikere R. Sridhar* \\ Department of Biosciences, Mangalore University, Mangalagangotri, Mangalore 574 199, India
}

\section{Abstract}

Inventory in different locations of the Western Ghats and west coast of India during 2011-2013 yielded six species of geasters (Geastrum fimbriatum, G. lageniforme, G. pseudostriatum, G. saccatum, G. schweinitzii and G. triplex). Based on fresh basidiomata, illustrations of geasters are presented with macroscopic and microscopic observations. Fruit bodies of G. lageniforme were gregarious and abundant followed by G. triplex, while G. pseudostriatum were rare and solitary. Among the geasters, G. triplex was ectomycorrhizal with native tree Terminalia paniculata of the west coast. Geastrum fimbriatum, G. pseudostriatum and G. schweinitzii constitute the first record for the Western Ghats of India. Distribution, substrate preference, ectomycorrhizal features, economic value and conservation of geasters are discussed.

Keywords: Basidiomycota; Gasteromycetes; Geastraceae; Geastrum; gasteroid fungi; earthstars

\section{Introduction}

Geastrum (phylum: Basidiomycota; order: Geasterales; family: Geastraceae) is a cosmopolitan genus among the gasteroid fungi possessing enclosed hymenophore and commonly known as earthstars as exoperidium dehisce like star [1,2]. The genus Geastrum was erected by Persoon [3] with G. coronatum as type species. This genus has been generally characterized by pointed globose or sub-globose puffball with four-layered peridium buried in litter or soil or humus strata without stipe and pileus consisting of brown globose or sub-globose spores with verrucose or echinulate surface. Traditional

\footnotetext{
*Corresponding author. Email: kandikere@gmail.com

Handling Editor: Maria Rudawska
} 
taxonomy of geasters mainly relay on morphological traits like peristome type (fibrillose or sulcate), its delimitation with rest of the body, presence or absence of connecting stalk between exoperidium and endoperidium, hygroscopic nature of exoperidial rays and structure of mycelial layer [1,2,4-6]. Recently, Zamora et al. [7] considered two important characteristics (macrochamical tests to detect phenoloxidase and crystalline deposits from rhizomorphs), which were not previously used for identification of Geastrum species. Most recently, the systematics of the genus Geastrum has been revisited using morphological, chemical and molecular phylogenetic approaches [8-11].

According to the dictionary of fungi by Kirk et al. [12] and Perez [13], 50 species of Geastrum have been described worldwide. However, based on herbarium specimens and field work, Zamora et al. [10,11] suggest the existence up to 100-120 species under the genus Geastrum. Hosaka et al. [14] proposed a new subclass Phallomycetidae in the order Geastrales. Phylogenetic relationship has been established between Gasteromycete and Geastrum spp. by sequencing large subunit of rDNA [15,16]. Kasuya et al. [8] carried out molecular studies for the phylogenetic placement of Geastrum melanocephalum and Geastrum triplex, while Zamora et al. [17] redescribed a forgotten species of Geastrum argentinum based on molecular traits. Jeppson et al. [9] established phylogenetic relationships of European earthstars based on molecular sequence data (nuclear rDNA ITS1 and ITS2; LSU; Tef- $\alpha$ ), morphological and ecological characteristics. However, substantial variation in sequence has been reported between morphologically similar taxa in Geastraceae [15,18-20]. Tedersoo et al. [21] studied the diversity, distribution and evolution of phylogenetic lineages among the ectomycorrhizal geasters.

Geasters in tropical region (e.g. Argentina, Bolivia, Brazil, Costa Rica, eastern Central Africa and West Africa) have been studied by various investigators [16,22,23]. Many geasters occurring in the European region have been categorized under threatened, critically endangered and red listed (e.g. Bulgaria, Czech Republic, Montenegro, Poland, Slovakia, Sweden and Switzerland) [24-26]. Western Ghats and west coast of India encompass a wide variety of habitats (e.g. forest reserves, sacred groves, agroforests, mangroves and sand dunes) supporting diverse macrofungal population. Several studies have been carried out in the Western Ghats and west coast region to document the distribution, richness and diversity of macrofungi [27-33]. Literature search reveals a few reports on the occurrence of geasters in the southern India (including the Western Ghats) [29,31,32,34-37] and northern India [38-40]. Several interesting geasters were recovered during the current inventory on macrofungi in selected habitats of the Western Ghats and west coast of India. Thus, this paper presents the occurrence, distribution, habitats, substrate and morphological description of six species of geasters.

\section{Material and methods}

Survey was undertaken during southwest monsoon and post-monsoon seasons in 2011-2013 by opportunistic and transect methods. Inventory of geasters was carried out in forest reserves, Shola forests, coffee agroforests and sacred groves in the Western Ghats (Kodagu, Karnataka State). In the west coast (Mangalore, Karnataka State), locations surveyed for geasters include arboretum, Anacardium plantation, Areca agroforest, Pongamia plantation and Terminalia dominant mixed forest. 
Recorded geasters were identified based on general morphological traits [41-43] and color codes [44] followed by precise characteristic features of Geastrum fimbriatum, G. lageniforme, G. pseudostriatum, G. saccatum, G. schweinitzii and G. triplex consulting various literature sources $[8,9,13,25,32,45-54]$.

Measurement of basidiomata, mature fruit bodies and spore sac was the average of 10 specimens except for G. pseudostriatum (5 specimens), while measurement of basidiospores (mounted in phosphate-buffered-saline) inclusive of ornamentation was based on the average of 25 spores using 100× objective of Olympus System Microscope (CX41RF, USA). Selected specimens were cleaned and fixed in a mixture of water-ethanol-formaldehyde (14:5:1) and deposited in the mycological herbarium of the Department of Biosciences, Mangalore University (MUBSNCKKRSMF\#034-039).

\section{Results and description}

A total six species of geasters (Geastrum fimbriatum, G. lageniforme, G. pseudostriatum, G. saccatum, G. schweinitzii and G. triplex) were recorded in different habitats of the Western Ghats and west coast. Among the locations surveyed, specific habitats endowed with geasters in the Western Ghats were coffee agroforests of B'Shettigeri $\left(12^{\circ} 12^{\prime} \mathrm{N}\right.$, $\left.75^{\circ} 88^{\prime} \mathrm{E}\right)$, sacred groves of Betoli $\left(12^{\circ} 18^{\prime} \mathrm{N}, 75^{\circ} 78^{\prime} \mathrm{E}\right)$ and Acacia forests in Madikeri $\left(12^{\circ} 42^{\prime} \mathrm{N}, 75^{\circ} 74^{\prime} \mathrm{E}\right)$. Four habitats in the west coast $\left(12^{\circ} 48^{\prime} \mathrm{N}, 74^{\circ} 55^{\prime} \mathrm{E}\right)$ consists of geasters were Terminalia dominant mixed forest, Pongamia dominant mixed forest, arboretum (endemic and endangered tree species of the Wedstern Ghats) and plantations of Anacardium. Fruit bodies of G. lageniforme were the most abundant followed by G. triplex and G. schweinitzii. Geastrum fimbriatum and G. saccatum occur rarely either solitary or in pairs, while G. pseudostriatum was very rare and solitary. Among the geasters, G. triplex was ectomycorrhizal with native tree species (Terminalia paniculata) of the west coast.

\section{Geastrum fimbriatum Fr.}

Pale greyish-brown bulb surmounting a star-shaped ochraceous-brown base, which raises the spore sac above the surrounding substrate. Solitary or in pairs, rare to infrequent, annual, humicolous or particolous, taste and odor not distinctive and edible. Fully matured fruit body measures $3.5(3.2-3.8) \mathrm{cm}$ diam $\times 1.6(1.5-1.7) \mathrm{cm}$ tall. Geastrum fimbriatum differs from other species in possessing ochraceous-brown fruit body, fimbriate peristome and saccate to involute exoperidium (Fig. 1a-c).

Immature basidiomata hypogeous, spherical to oval, brown, fibrous to squamulose and measures $1.8(1.6-2) \mathrm{cm}$ diam $\times 1.3(1.2-1.4) \mathrm{cm}$ tall. Basidiomata becomes epigeous on maturity, exoperidium splits into 7-9 non-hygroscopic or semi-hygroscopic starfish-like rays; at first saccate, become involute and rarely arched. Pseudoparenchymatous layer initially creamish-pink fading to ochraceous-brown with age. Mycelial layer encrusted with debris. Endoperidial body (spore sac) sub-spherical, sessile, devoid of apophysis and measures $1.6(1.5-1.7) \mathrm{cm}$ diam. Endoperidium initially beige becoming tan and pale greyish-brown with age, thin and papery. Peristome undelimited, pale, fimbriate to fibrillose, broadly conical and devoid of distinct halo region. Gleba (spore mass) at first pallid and firm becoming brown and powdery with age. Spores brownish, spherical, spiny and measures $3.9(3.4-4.5) \mu \mathrm{m}$ diam with ornamentation. 

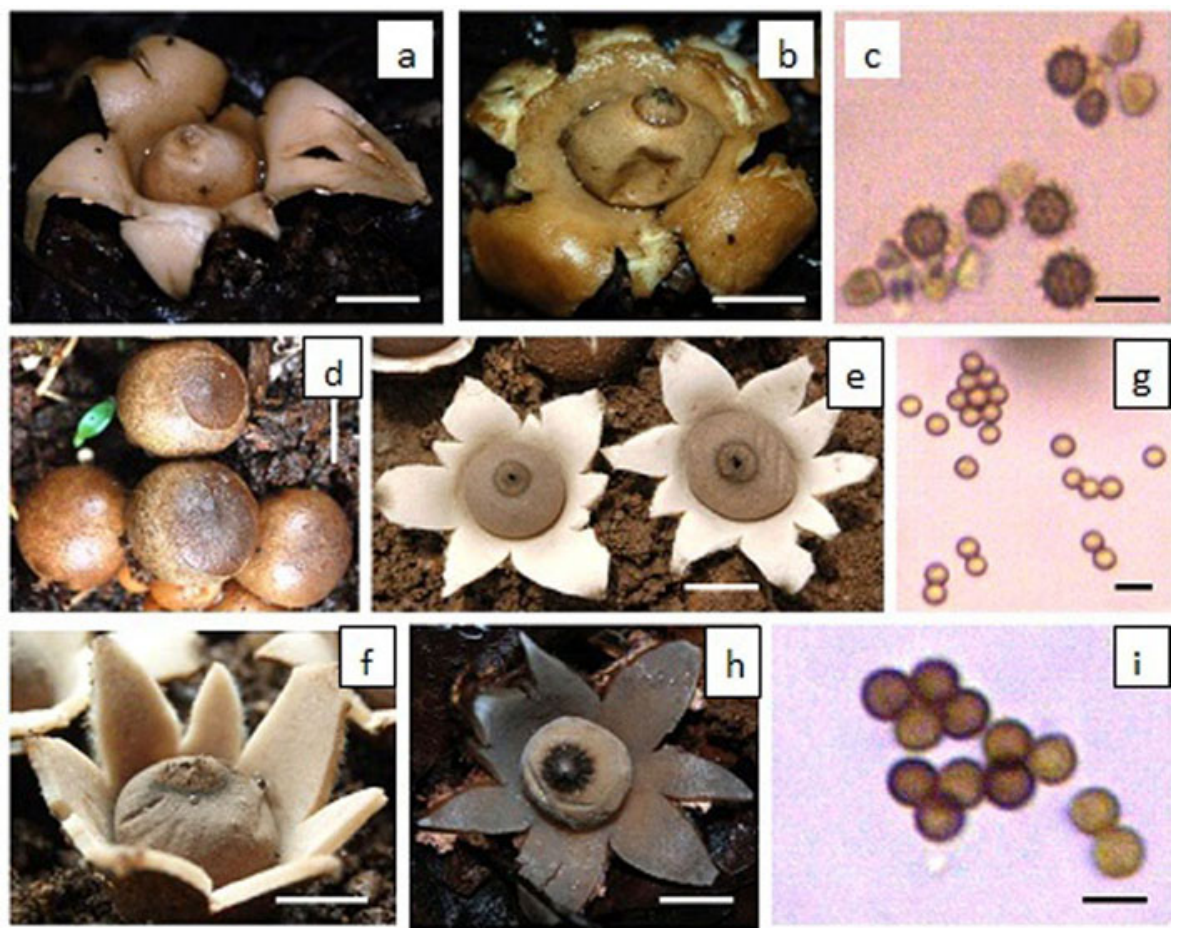

Fig. 1 Maturing fruit body arising from humus (a), matured fruit body on humus (b) and spiny spores (c) of Geastrum fimbriatum; immature fruit bodies arising from soil and woody debris (d), mature fruit bodies on soil (e), mature fruit body showing hairy peristome (f) and spiny spores (g) of Geastrum lageniforme; mature fruit body with furrowed beak-like peristome (h) and spiny spores (i) of Geastrum pseudostriatum. Scale bars: $1 \mathrm{~cm}(\mathbf{a}, \mathbf{b}, \mathbf{d}-\mathbf{f}, \mathbf{h}) ; 5 \mu \mathrm{m}(\mathbf{c}, \mathbf{g}, \mathbf{i})$.

SUBSTRATE AND DISTRIBUTION. On soil along with mixed leaf litter of Artocarpus heterophyllus, Coffea robusta and Mangifera indica in coffee agroforest (Virajpet), Kodagu (July 15, 2013; N.C. Karun; MUBSNCKKRSMF\#034). Other macrofungi like Boletinellus merulioides and Ophiocordyceps nutans were associated with G. fimbriatum. Roots of Abies pindrow, Cedrus deodara, Pinus wallichiana and P. roxburghii were associated with G. fimbriatum in Dehra Dun forests of northern India [55]. This geaster was ectomycorrhizal with Shorea robusta in tropical moist deciduous forests in Madhya Pradesh, central India [38].

\section{Geastrum lageniforme Vittad.}

Brownish bulb surmounting a star-shaped creamish brown base, which raises the spore sac above the surrounding substrate. Gregarious or in small (6-7 fruit bodies in the Western Ghats) to large (20-30 fruit bodies in the west coast) troops, infrequent, annual, lignicolous, taste and odour not distinctive and inedible. Matured fruit body measures $3.4(1.9-4.3) \mathrm{cm}$ diam $\times 2.2(1.6-2.7) \mathrm{cm}$ tall. Geastrum lageniforme differs from other 
species in possessing fibrillate peristome, arachnoid basidiomata and spores of 2.5-3.5 $\mu \mathrm{m}$ diam (Fig. 1d-g).

Immature basidiomata epigeous, brown, bulbous to sub-globose, surface coarsely fibrous to arachnoid and measures $2.02(1.6-2.3) \mathrm{cm}$ diam $\times 1.9(1.4-2.2) \mathrm{cm}$ tall. At maturity exoperidium splits into 6-9 non-hygroscopic petal-like lobes; slightly incurved during dry condition, while recurved in moist condition and saccate. Pseudoparenchymatous layer at first pinkish cream, becoming pale creamish brown with age. Mycelial layer is felty but does not encrust wood/bark and there is a basal attachment point to the below ground mycelium. Endoperidial body sub-spherical, $1.4(0.9-1.8) \mathrm{cm}$ diam and sessile devoid of apophysis. Endoperidium brownish with purple shade, thin, papery and covered by fine whitish pruina (or mesoperidium) in newly expanded basidiomata. Peristome delimited, fibrillate, creamish yellow to brownish, conically elevated and surrounded by a distinct brownish black halo region. Gleba at first pallid and firm, with age becoming brown and powdery. Spores dark brown, spherical, finely spiny and measure $2.8(2.4-3.2)$ $\mu \mathrm{m}$ diam (inclusive of ornamentations).

SUBSTRATE AND DISTRIBUTION. On soil mixed with decaying twigs and bark of Pongamia pinnata, Mangalore University campus (Mangalore; June 26, 2013; N.C. Karun; MUBSNCKKRSMF\#035). Agaricus spp. was found in the vicinity of G. lageniforme.

\section{Geastrum pseudostriatum Hollós}

Brownish grey pointed bulb surmounting a dark brownish star-shaped base, which raises the spore sac above the surrounding substrate. Solitary, infrequent to rare, annual, particolous, taste and odor not distinctive and inedible. Matured fruit body measures 3.2 $(2.9-3.5) \mathrm{cm}$ diam $\times 1.9(1.7-2.1) \mathrm{cm}$ tall. Geastrum pseudostriatum differs from other species in possessing brownish-black, sulcate beak like peristome, very short stalked apophysis under endoperidial body and arched exoperidium (Fig. 1h,i).

Immature basidiomata hypogeous, ochraceous brown, sub-spherical to oval, fibrous and measures $2.1(1.8-2.3) \mathrm{cm}$ diam $\times 1.7(1.5-1.9) \mathrm{cm}$ tall. At maturity epigeous, exoperidium splits into 7-8 non-hygroscopic (or sometimes slightly hygroscopic) starfish-like rays; initially flat becoming arched. Pseudoparenchymatous layer initially greyish pink to pallid brown becoming brownish and persistent with age. Mycelial layer encrusted with debris. Endoperidial body sub-spherical to oval, $1.3(1.1-1.5) \mathrm{cm}$ diam and stalked with an apophysis (seen distinctly in older specimens). Endoperidium dull grey brown to brownish grey, sand-paper-like, thin and covered with white farinaceous mesoperidium. Peristome blackish brown, sulcate to furrowed beak like, conically protruding and without a distinct halo region. Gleba at first pallid and firm, with age becoming brown and powdery. Spores sub-spherical, distinctly ornamented, dark-brown and measure 5 (4.4-5.5) $\mu \mathrm{m}$ diam (inclusive of ornamentations).

SUBSTRATE AND DISTRIBUTION. On soil along with leaf litter of Canarium strictum and Dysoxylum malabaricum in sacred grove (Betoli), Kodagu (August 25, 2012; N.C. Karun; MUBSNCKKRSMF\#036). Scleroderma areolatum was found in the vicinity of G. pseudostriatum.

Based on morphological, ecological and molecular sequence data, Jeppson et al. [9] reported that G. pseudostriatum is closely related to Geastrum berkeleyi. But, the latter requires nutrient-rich wooded/bushy habitats and produce large fruit bodies with small spores. 


\section{Geastrum saccatum Fr.}

Creamish brown bulb surmounting a star-shaped creamish base, which raises the spore sac above the surrounding substrate. Solitary or in pairs, infrequent, annual, humicolous, taste and odor not distinctive and medicinal. Mature fruit body measures $2.85(2.7-2.95) \mathrm{cm}$ diam $\times 1.15(1.1-1.2) \mathrm{cm}$ tall. Geastrum saccatum differs in possessing pallid/creamish fruit body, fimbrillate peristome, dented concolours halo region and saccate exoperidium (Fig. 2a-c).

Immature basidiomata epigeous, creamish brown, sub-globose to oval, fibrous to squamulose and measures $1.45(1.35-1.55) \mathrm{cm}$ diam $\times 1(0.9-1.1) \mathrm{cm}$ tall. At maturity exoperidium splits into 8 pointed non-hygroscopic starfish-like rays; rays are split at apex, involute and saccate. Pseudoparenchymatous layer pale creamish pink. Mycelial layer is felty but does not encrust litter and there is a basal attachment point to the below ground mycelium. Endoperidial body sub-spherical, $1.25(1.2-1.3) \mathrm{cm}$ diam, sessile and devoid of apophysis. Endoperidium pale creamish brown, thin and papery. Peristome delimited, pale, fimbrillate, conically protruding and surrounded by a finely depressed circular halo region. Gleba at first pallid and firm, with age becoming brown and powdery. Spores brownish, spherical, spiny and measure $2.9(2.63-3.16) \mu \mathrm{m}$ diam (inclusive of ornamentations).

SUBSTRATE AND DISTRIBUTION. On soil along with mixed leaf litter of Canarium strictum, Dysoxylum malabaricum and Holigarna nigra in Betoli sacred grove, Kodagu (July 27, 2012; N.C. Karun; MUBSNCKKRSMF\#037). Scleroderma areolatum was found in the vicinity of G. saccatum. Geastrum saccatum was recorded on the decaying logs in Western Ghat region of Kerala [32] and it was also found in the urban locations of southern India [35].

\section{Geastrum schweinitzii (Berk. \& M.A. Curtis) Zeller}

Greyish brown bulb surmounting a star-shaped pinkish brown base, which raises the spore sac above the surrounding substrate. Occurs in small groups/caespitose (10-15 fruit bodies), rare, annual, humicolous or lignicolous, taste and odor not distinctive. Mature fruit body measures $1.3(0.9-1.7) \mathrm{cm}$ diam $\times 0.7(0.4-1) \mathrm{cm}$ tall. Geastrum schweinitzii differs from other species in possessing very small fruit body, brownish fimbrillate peristome, saccate to elongated exoperidium narrowing at the base near the subiculum (Fig. $2 \mathrm{~d}-\mathrm{j}$ ).

Immature basidiomata epigeous, mud brown to creamish brown, oval to ellipsoidal, fibrous to finely hirsute, narrowing towards the base or rarely with a very short stipe or false stipe attached to mycelium and measures $0.6(0.4-0.7) \mathrm{cm}$ diam $\times 0.7(0.4-0.8) \mathrm{cm}$ tall. At maturity, the exoperidium splits into 5-7 non-hygroscopic petal-like lobes; petals split at the apex, saccate and elongated. Pseudoparenchymatous layer pinkish-brown. Mycelial layer is exposed and the subiculum develops on the debris. Endoperidial body spherical to sub-spherical, $0.5(0.35-0.7) \mathrm{cm}$ diam, sessile and without apophysis. Endoperidium greyish brown, thin and papery. Peristome brown, delimited by a line, fimbrillate, slightly elevated and surrounded by a distinct pale halo region. Gleba at first pallid and firm, becoming brown and powdery with age. Spores dark purple brown, spherical, spiny and measure 3.92 (3.42-4.47) $\mu \mathrm{m}$ diam (inclusive of ornamentations).

SUBSTRATE AND DISTRIBUTION. On the phyllode and bark debris of Acacia auriculiformis plantation (Madikeri), Kodagu (September 15, 2002; N.C. Karun) [56]. On the phyllode litter of A. auriculiformis and twigs of Sapium insigne in cashew (Anacardium 

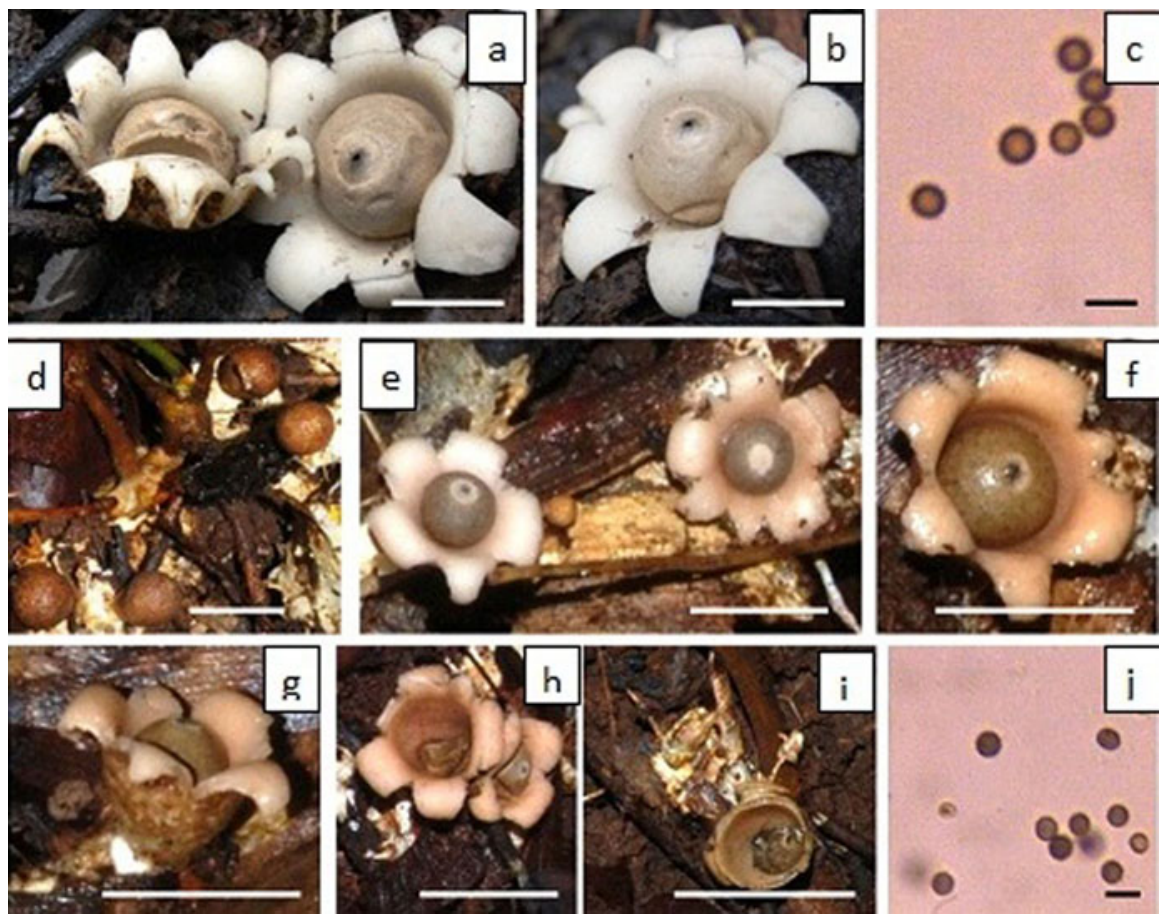

Fig. 2 Mature fruit bodies arising from humus (a,b) and spiny spores (c) of Geastrum saccatum; immature fruit bodies on leaf litter (d), maturing fruit bodies (e), top view of matured fruit body (f), side view of matured fruit body showing elongated saccate-like exoperidium (g), partially degraded fruit bodies (h), degraded fruit body showing cup-like exoperidial remnant (i) and spiny spores (j) of Geastrum schweinitzii. Scale bars: $1 \mathrm{~cm}(\mathbf{a}, \mathbf{b}, \mathbf{d}-\mathbf{i}) ; 5 \mu \mathrm{m}(\mathbf{c}, \mathbf{j})$.

occidentale) plantation, Mangalore University campus (Mangalore; August 19, 2011; N.C. Karun; MUBSNCKKRSMF\#038). In both locations, Marasmius spp. was found in the vicinity of G. schweinitzii.

\section{Geastrum triplex Jungh.}

Greyish-brown bulb surmounting a star-shaped pinkish brown base, which raises the spore sac above the surrounding substrate. Scattered or in small troops (25-30 fruit bodies), rare, annual, particolous, taste and odor not distinctive, edible and medicinal. Mature fruit body measures $6.7(4.6-8.6) \mathrm{cm}$ diam $\times 4.1(3.1-5.4) \mathrm{cm}$ tall. Geastrum triplex differs from other species in possessing fibrillate peristome and saucer-like base beneath the spore sac with exoperidial rays rolled/curled upward-inward under the endoperidial body (Fig. 3a-g).

Immature basidiomata hypogeous, dull orange brown, onion- or pear-shaped, coarsely fibrous to squamulose and measures $2.6(2.3-2.9) \mathrm{cm}$ diam $\times 2.9(2.7-3.2) \mathrm{cm}$ tall. At maturity, epigeous, exoperidium splits into 5-6 non-hygroscopic starfish-like rays; involute 
and later curl upwards and inwards under the endoperidial body. Pseudoparenchymatous layer initially pinkish brown fading to brown with age, concentrically fissured to form a saucer-like base under the endoperidium. Mycelial layer not encrusted with soil, radially fissured and there is a basal attachment point to the belowground mycelium. Endoperidial body spherical to sub-spherical, $2.7(2.1-2.9) \mathrm{cm}$ diam, sessile and surmounting a saucer-like base. Endoperidium greyish brown, thin, papery and smooth. Peristome delimited, fibrillate, creamish to brown, conically elevated and surrounded by a distinct pallid to brownish black halo. Gleba at first pallid and firm, with age becoming brown and powdery. Spores brownish, spherical, spiny and measure 4.5 (4-4.7) $\mu \mathrm{m}$ diam (inclusive of ornamentations).

SUBSTRATE AND DISTRIBUTION. On soil along with litter in Terminalia dominant mixed forest in Mangalore University campus (Mangalore; August 12, 2011; September 12, 2012, July 17, 2013; N.C. Karun; MUBSNCKKRSMF\#039). Marasmius sp., Termitomyces umkowaan and Xylaria sp. were found in the vicinity of G. triplex. Geastrum triplex is ectomycorrhizal with Terminalia paniculata, and was also found in the vicinity of the tree bases of Artocarpus heterophyllus, Canarium strictum and Mangifera indica in arboretum of the west coast. Geastrum triplex occurred in grasslands and moist-deciduous to Shola forests in Sasthanada, Kerala [32]. It was also recorded from the forest locations dominated by T. paniculata in Kuvempu University campus (Karnataka) [37]. This geaster was ectomycorrhizal with Shorea robusta in tropical moist deciduous forests of central India [38].

According to Kasuya et al. [8], G. triplex is highly polyphyletic as the collar-forming Geastrum spp. are usually recognized under G. triplex-complex. But, the European and

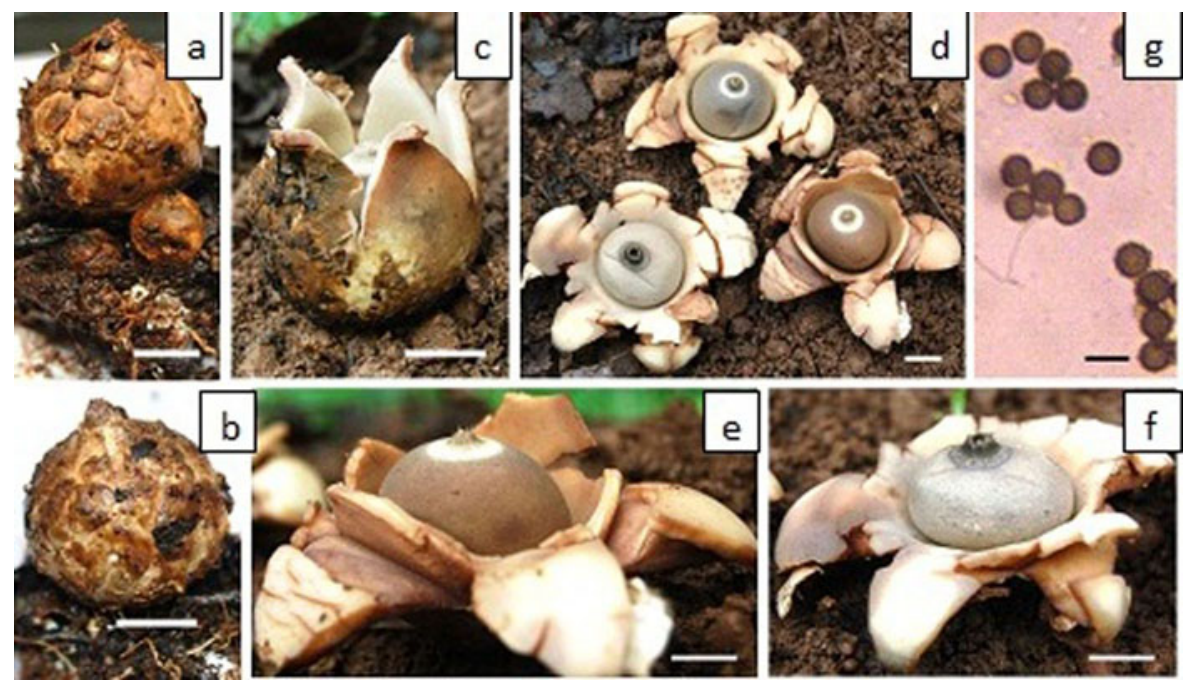

Fig. 3 Different stages of immature fruit bodies (a), onion-shape immature fruit body (b; a,b: scooped out basidiomata with rhizoidal connection with tree roots), partially dehisced fruit body (c), different stages of matured fruit bodies (d), unopened hairy peristome of mature fruit body (e), opened hairy peristome of mature fruit body (f) and spiny spores (g) of Geastrum triplex (note the connections of immature fruit bodies at the basal region with roots of Terminalia paniculata). Scale bars: $1 \mathrm{~cm}(\mathbf{a}-\mathbf{f}) ; 5 \mu \mathrm{m}(\mathbf{g})$. 
North American holotypes of G. triplex are not exactly similar with those from the Indonesia [8]. Interestingly, the European G. triplex has been recently renamed as Geastrum michelianum by Zamora et al. [10]. Further molecular studies are necessary to obtain more precise insight on this complex.

\section{Discussion and outlook}

Unidentified species of geasters were recorded in moist-deciduous forests, semievergreen forests, sacred groves and coffee plantations of the Western Ghats of Karnataka [29,31]. In the Western Ghat region of Kerala, G. saccatum was recorded on the decaying logs [32]. Recently it was also found in the urban locations of southern India [35]. In the present study several locations in the Western Ghats and west coast of India has been surveyed for geasters and revealed that they were confined to specific habitats. They were restricted to the coffee agroforests, sacred groves, the forest reserves and Shola forests in the Western Ghats. Geastrum saccatum were found in Terminalia dominant mixed forest, Anacardium or Pongamia plantations and in Areca dominant plantations in the west coast. However, in the Western Ghats of Kerala, geasters were recovered in moist deciduous, semi-evergreen, evergreen and Shola forests and grasslands [32]. According to Mohanan [32], geasters in Western Ghats are usually terrestrial, rarely lignicolous or coprophilous. In our study, fruit bodies of geasters were mainly observed at the soil surrounded with leaf litter and humus except for G. lageniforme and G. schweinitzii. Geastrum lageniforme preferred soil mixed with decomposing twigs or bark of Pongamia, while G. schweinitzii was found directly on the phyllodes of Acacia auriculiformis and decaying twigs of latex-yielding plant, Sapium insigne (see Fig. 2e). Besides of our studies, the occurrence of G. schweinitzii has also been noted in Brazil [13,48].

Although Natarajan et al. [28] have reported several ectomycorrhizal fungi in dipterocarp forest of the Western Ghats, none of them belongs to the genus Geastrum. Generally the genus Geastrum is believed to be saprotrophic with an exception of one published record from Germany indicating a mycorrhizal connection between G. fimbriatum and Fagus sylvatica [57]. In our study, G. fimbriatum which occurred in the vicinity of Artocarpus heterophyllus, Coffea robusta and Mangifera indica in coffee plantations in the Western Ghats needs further survey to reveal its ectomycorrhizal nature. Bakshi [55] has reported association of roots of Abies pindrow, Cedrus deodara, Pinus wallichiana and $P$. roxburghii with G. fimbriatum in Dehra Dun forests of northern India. Geastrum triplex was gregarious, partially growing on soil and connected underneath to the feeder roots of timber yielding tree, Terminalia paniculata in the west coast region. Preliminary microscopic examinations revealed the presence of mycelial mantle around the roots and direct connection of mycelia with roots. Geastrum triplex is common in humus accumulated moist forest floor in the vicinity of T. paniculata with thick canopy cover especially during mid rainy season (August). This geaster has been consistently discovered in such habitats over a decade. Geastrum triplex was found close to the tree bases of Artocarpus heterophyllus (fruit and timber yielding), Canarium strictum (resin and canoe wood yielding) and Mangifera indica (fruit and fuel wood yielding) in 20 years old arboretum consisting of endemic and endangered trees of the Western Ghats. Geastrum triplex similarly to G. fimbriatum needs further studies to confirm its ectomycorrhizal association 
with different host tree species. Occasionally G. triplex has been collected from the forest locations dominated by T. paniculata in Kuvempu University campus (Karnataka) [37]. Geastrum triplex was found to be ectomycorrhizal in Sal trees (Shorea robusta) in tropical moist deciduous forest in Madhya Pradesh, central India [38]. Puffballs are known for many traditional uses (e.g. aesthetic, decorative, dietary and medicinal) [58-60]. Geasters are used for prophylactic and therapeutic applications in newborn infants [60] and to clear the discharges from ear [61]. Among the geasters recorded in the present study, G. fimbriatum is edible in India and Madagascar, G. saccatum is medicinal fungus in Mexico and G. triplex is edible and medicinal in India and Mexico, and G. triplex is also medicinal in Guyana [59]. According to Soosairaj et al. [36], wild G. fimbriatum growing on the wood debris is edible in the southeastern India. Dore et al. [62] has reported anti-inflammatory, antioxidant and cytotoxic actions of extract from G. saccatum. Solvent extracts of $G$. triplex were also active against several plant and human pathogenic bacteria [37]. Squeezing the spore sac of G. saccatum and G. triplex releases spores in to bee hives and anesthetize bees for about $30 \mathrm{~min}$ facilitating harvest of honey [63].

Several geasters occurring in Europe have been considered as threatened, critically endangered and red listed (e.g. Bulgaria, the Czech Republic, Montenegro, Poland, Slovakia, Sweden and Switzerland) [24-26,64]. Esqueda et al. [66] have proposed priority regions for conservation of biodiversity of geasters in Mexico. However, Nitare [66] and Benkert [67] opined that geasters serve as indicators of specific habitats in need of conservation. There is a general opinion worldwide that geasters are under threat due to anthropogenic pressures and thus those locations endowed with geasters needs special attention for restoration and conservation.

\section{Acknowledgments}

Authors are grateful to Mangalore University for permission to carry out this study in the Department of Biosciences. We are indebted for specific suggestions and literature to improve our manuscript by Drs. María P. Martín, Spain and Larissa Trierveiler-Pereira, Brazil. We thank the Editor-in-Chief and two anonymous referees for genuine comments and suggestions to improve the earlier version of the manuscript. NCK acknowledges Mangalore University for partial financial support through fellowship under the "Promotion of University research and scientific excellence" (PURSE), Department of Science Technology, New Delhi. KRS is grateful to the University Grants Commission, New Delhi for the award of UGC-BSR Faculty Fellowship.

\section{Authors' contribution}

The following declarations about authors' contributions to the research have been made: collection of material, field and laboratory observations, identification, collection and assessment of literature: NCK, KRS; photography: NCK; manuscript drafting: KRS, NCK.

\section{References}

1. Sunhede S. Geastraceae (Basidiomycotina). Morphology, ecology and systematics with special emphasis on the North European species. Synopsis Fungorum. 1989;1:1-534.

2. Ponce de León P. A revision of the family Geastraceae. Fieldiana. Botany. 1968;31:301-349.

3. Persoon CH. Synopsis Methodica Fungorum 2. Gottingen: Henricus Dieterich 1801.

4. Staněk VJ. Geastraceae. In: Pilát A. editor. Flora ČSR B1 Gasteromycetes: Praha; 1958. p. 392-526.

5. Sunhede S. Geastrum Pers. In: Knudsen H, Vesterholt J, editors. Funga Nordica. Agaricoid, boletoid, clavarioid, cyphelloid and gastroid genera. Copenhagen: Nordsvamp; 2012. p. 96-100. 
6. Calonge FD. Gasteromycetes. I. Lycoperdales, Nidulariales, Phallales, Sclerodermatales, Tulostomales. Flora Mycol Iberica. 1998;3:1-271.

7. Zamora JC, Calogne FD, Martín MP. New sources of taxonomic information for earthstars (Geastrum, Geastraceae, Basidiomycota): phenoloxidases and rhizomorph crystals. Phytotaxa. 2013;132:1-20.

8. Kasuya T, Hosaka K, Uno K, Kakishima M. Phylogenetic placement of Geastrum melanocephalum and polyphyly of Geastrum triplex. Mycoscience. 2012;53:411-426.

9. Jeppson M, Nilsson RH, Larsson E. European earthstars in Geastraceae (Geastrales, Phallomycetidae) - a systematic approach using morphology and molecular sequence data. Systematics and Biodiversity. 2013;11:437-465.

10. Zamora JC, Calogne FD, Hosaka K, Martín MP. Systematics of the genus Geastrum (Fungi: Basidiomycota) revisited. Taxon. 2014;63:477-497. http://dx.doi.org/10.12705/633.36

11. Zamora JC, Calogne FD, Martín MP. Combining morphological and phylogenetic analyses to unravel systematics in Geastrum sect. Schmidelia. Mycologia. 2014;106(6):1199-1211. http://dx.doi.org/10.3852/14-072

12. Kirk PM, Cannon PF, Minter DW, Stalpers JA. Ainsworth and Bisby's dictionary of the Fungi. 10th ed. Wallingford: CABI; 2008.

13. Perez EF. O gênero Geastrum Pers. (Phallomycetidae, Basidiomycota) em Algumas Áreas De Mata Atlántica E Caatinga No Rio Grande Do Norte, Brasil [MSc thesis]. Natal: Universidade Federal Do Rio Grande Do Norte; 2009.

14. Hosaka K, Bates ST, Beever RE, Castellano MA, Colgan III W, Domínguez LS, et al. Molecular phylogenetics of the gomphoid-phalloid fungi with an establishment of the new subclass Phallomycetidae and two new orders. Mycologia. 2006;98:949-959. http://dx.doi.org/10.3852/mycologia.98.6.949

15. Hibbett DS, Pine PM, Langer E, Donoghue MJ. Evolution of gilled mushrooms and puffballs inferred from ribosomal DNA sequences. Proc Natl Acad Sci USA. 1997;94:12002-12006.

16. Douanla-Meli D, Langer E, Calonge FD. Geastrum pleosporus sp. nov., a new species of Geastraceae identified by morphological and molecular phylogenetic data. Mycol Prog. 2005;4:239-250. http://dx.doi. org/10.1007/s11557-006-0127-3

17. Zamora JC, Kuhar F, Castiglia V, Papinutti L. On Geastrum argentinum, a forgotten species. Mycoscience. 2014;55:177-182. http://dx.doi.org/10.1016/j.myc.2013.08.003

18. Kruger D, Binder M, Fischer M, Kreisel H. The Lycoperdales: a molecular approach to the systematics of some gasteroid mushrooms. Mycologia. 2001;93:947-957.

19. Binder M, Bresinky A. Derivation of a polymorphic lineage of gasteromycetes from boletoid ancestors. Mycologia. 2002;94:85-98.

20. Demoulin V, Cornet L, Delbruyère E, Baurain D. The unusual Gasteromycetes Lycogalopsis solmsii belongs to the gomphoid-phalloid group. Acta Mycol. 2013;48:13-20. http://dx.doi.org/10.5586/am.2013.002

21. Tedersoo L, May TW, Smith ME. Ectomycorrhizal lifestyle in fungi: global diversity, distribution, and evolution of phylogenetic lineages. Mycorrhiza. 2010;20:217-163. http://dx.doi.org/10.1007/s00572-009-0274-x

22. Kuhar F, Papinutti L. Geastrum episcopale: a new noticeable species with red-violet exoperidium. Mycologia. 2009;101:535-538. http://dx.doi.org/10.3852/08-029

23. Trierveiler-Pereira L, Stantos PJP, Baseia IG. Ecological aspects of epigeous gasteromycetes (Agaricomycetes, Basidiomycota) in four remnants of the Brazilian Atlantic Forest. Fungal Ecol. 2013;6:471-478. http:// dx.doi.org/10.1016/j.funeco.2013.09.002

24. Wojewoda W, Ławrynowicz M. Red list of the macrofungi in Poland. In: Mirek Z, Zarzycki K, Wojewoda W, Szeląg Z, editors. Red list plants and fungi in Poland. Karków: W Szafer Institute of Botany, Polish Academy of Sciences; 2006. p. 53-70.

25. Jeppson M. Åtgärdsprogram för jordstjärnstryffel 2007-2011 (Radiigera flexuosa). Stockholm: Naturvårdsverket; 2009.

26. Piętka J, Kujawa A. A new location for Geastrum lageniforme Vittad. in Poland. Pol J Environ Stud. 2012;21:1791-1795.

27. Natarajan K, Narayanan K, Ravindran C, Kumaresan V. Biodiversity of agarics from Nilgiri Biosphere Reserve, Western Ghats, India. Curr Sci. 2005;88:1890-1893. 
28. Natarajan K, Senthilarasu G, Kumaresan V, Riviere T. Diversity in ectomycorrhizal fungi of a dipterocarp forest in Western Ghats. Curr Sci. 2005;88:1893-1895.

29. Bhagwat S, Kushalappa C, Williams P, Brown N. The role of informal protected areas in maintaining biodiversity in the Western Ghats of India. Ecol Soc. 2005;10(1):8

30. Brown N, Bhagwat S, Watkinson S. Macrofungal diversity in fragmented and disturbed forests of the Western Ghats of India. J Appl Ecol. 2006;43:11-17. http:/dx.doi.org/10.1111/j.1365-2664.2005.01107.x

31. Swapna S, Abrar S, Krishnappa M. Diversity of macrofungi in semi-evergreen and moist deciduous forest of Shimoga District, Karnataka, India. J Mycol Plant Pathol. 2008;38:21-26.

32. Mohanan C. Macrofungi of Kerala. Kerala Forest Research Institute handbook \# 27. Peechi: Kerala Forest Research Institute; 2011.

33. Farook VA, Khan SS, Manimohan P. A checklist of agarics (gilled mushrooms) of Kerala State, India. Mycosphere. 2013;4:97-131. http://dx.doi.org/10.5943/mycosphere/4/1/6

34. Mani S, Kumaresan V. Occurrence of macrofungi on the Coromandel coast of Tamil Nadu, southern India. Journal of Threatened Taxa. 2009;1:54-57.

35. Pushpa H, Purushothama KB. Biodiversity of mushrooms in and around Bangalore (Karnataka), India. Am Eurasian J Agric Env Sci. 2012;12:750-759. http://dx.doi.org/10.5829/idosi.aejaes.2012.12.06.56401

36. Soosairaj S, Raja P, Kala A, Raj PK. Survey of macroscopic fungi from a few Districts of Tamil Nadu. The Bioscan. 2012;7:669-671.

37. Chittaragi A, Naika R, Ashwani HS, Nagaraj K. Antibacterial potential of Geastrum triplex Jungh. against plant and human pathogens. International Journal of Pharmtech Research. 2013;5:1456-1464.

38. Sharma R, Rajak RC, Pandy AK. Ectomycorrhizal mushrooms in Indian tropical forests. Biodiversity. 2009;10:25-30. http://dx.doi.org/10.1080/14888386.2009.9712634

39. Kumar S, Sharma YP. Systematics studies on Geastrum species from Jammu Province. J Sci Appl Res. 2012;3:61-64.

40. Srivastava AK, Soreng PK. Morphology, occurrence, natural habitat, structure and texture of Geastrum. Int J Rec Tr Sci Technol. 2012;4(2):101-103.

41. Jordan M. The encyclopaedia of fungi of Britain and Europe. London: Francis Lincoln Publishers Ltd.; 2004.

42. Phillips R. Mushrooms. London: Pan Macmillan; 2006.

43. Buczacki S. Collins fungi guide. London: Harper-Collins Publishers; 2012.

44. Anonymous Pantone color formula guide. New York, NY: Pantone Customer Service; 1995.

45. Bates S.T. Arizona members of the Geastraceae and Lycoperdaceae (Basidiomycota, Fungi) [MSc thesis]. Phoenix, AZ: Arizona State University; 2004.

46. Trierveiler-Pereira L, Bezerra KMT, Bezerra JL, Baseia IG. First records of Geastraceae and Nidulariaceae (Basidiomycota, Fungi) from Bahia, Northeastern Brazil. Rev Bras Biocienc. 2009;7:316-319.

47. Trierveiler-Pereira L, Gomes-Silva A, Baseia IG. Notes on gasteroid fungi of the Brazilian Amazon rainforest. Mycotaxon. 2009;110:73-80.

48. Trierveiler-Pereira L, Calonge FD, Baseia IG. New distributional data on Geastrum (Geastraceae, Basidiomycota) from Brazil. Acta Bot Brasilica. 2011;25:577-585. http://dx.doi.org/10.1590/S0102-33062011000300010

49. Trierveiler-Pereira L, Gomes-Silva A, Baseia IG. Observations on gasteroid Agaricomycetes from the Brazilian Amazon rainforest. Mycotaxon. 2011;118:273-282. http://dx.doi.org/10.5248/118.273

50. Moreno G, Lizárraga M, Esqueda M, Caronado ML. Contribution to the study of gasteroid and secotioid fungi of Chihuahua, Mexico. Mycotaxon. 2010;112:291-315. http://dx.doi.org/10.5248/112.291

51. Hemmes DE, Desjardin DE. Earthstars (Geastrum, Myriostoma) of the Hawaiian Islands including two new species, Geastrum litchiforme and Geastrum reticulatum. Pac Sci. 2011;65:477-496.

52. Trierveiler-Pereira L, Baseia IG. Contribution to the knowledge of gasteroid fungi (Agaricomycetes, Basidiomycota) from the state of Paraíba, Brazil. Rev Bras Biocienc. 2011;9:167-173.

53. Asef MR. Additions to the knowledge of the genus Geastrum in Iran. Rostaniha. 2012;13:21-30.

54. Caffot MLH, Robeledo G, Domínguez LS. Gasteroid mycobiota (Basidiomycota) from Polylepis australis woodlands of Central Argentina. Mycotaxon. 2013;123:1-12. 
55. Bakshi BK. Mycorrhiza and its role in forestry. Project report. Dehra Dun: Forest Research Institute; 1974.

56. Karun NC. Biodiversity of wood rotting fungi at various locations of Coorg [MSc thesis]. Madikeri: Mangalore University; 2002.

57. Agerer R, Beenken L. Geastrum fimbriatum Fr. + Fagus sylvatica L. Descr Ectomycorrhizae. 1998;3:13-18.

58. Burk WR. Puffball usages among North American Indians. J Ethanobiol. 1983;3:55-62.

59. Boa E. Wild edible fungi - a global overview of their use and importance to people. New Delhi: FAO (USA) and Daya Publishing House; 2007.

60. Mooney J, Olberchts FM. The swimmer manuscript, Cherokee sacred formulas and medicinal prescriptions. Smithson Inst Bur Am Ethnol Bull. 1932;99:1-319.

61. Robbins WW, Harrington JP, Freire-Marreco B. Ethnobotany of the Tewa Indians. Smithson Inst Bur Am Ethnol Bull. 1916;55:1-124.

62. Dore CMPG, Azevedo TCG, Souza MCR, Rego LA, Dantas JCM, Silva FRF, et al. Anti-inflammatory, antioxidant and cytotoxic actions of $\beta$-glucan-rich extract from Geastrum saccatum mushroom. Int Immunopharmacol. 2007;7:1160-1169.

63. Tibuhwa DD. Folk taxonomy and use of mushrooms in communities around Ngorongoro and Serengeti National Park, Tanzania. J Ethnobiol. Ethnomed. 2012;8:1-9. http://dx.doi.org/10.1186/1746-4269-8-36

64. Friedrich S. New locations of threatened and protected Gasteromycetes s.l. in northwestern Poland. Pol J Environ Stud. 2011;20:559-564.

65. Esqueda M, Herrera T, Pérez-Silva E, Sanchez A. Distribution of Geastrum species from some priority regions for conservation of biodiversity of Sonora, Mexico. Mycotaxon. 2003;87:445-456.

66. Nitare J. Signalarter. Indikatorer på skyddsvärd skog. Flora över kryptogamer. Jönköping: Skogsstyrelsen; 2000.

67. Benkert D. Berlin und die Mark Brandenburg-ein Paradies für Erdsterne (Geastrales). Verhandlungen des Botanischen Vereins von Berlin und Brandenburg. 2003;136:231-268. 